\title{
O332 Opportunistic infections in immunocompromised but virologically suppressed HIV-I infected patients
} WP Bannister*1, A Mocroft ${ }^{1}$, O Kirk ${ }^{2}$, P Reiss ${ }^{3}$, A d'Arminio Monforte ${ }^{4}$, JM Gatell ${ }^{5}$, M Fisher ${ }^{6}$, H Trocha ${ }^{7}$, A Rakhmanova ${ }^{8}$ and JD Lundgren ${ }^{2}$

Address: ${ }^{1}$ Royal Free and University College Medical School, London, UK, ${ }^{2}$ Copenhagen HIV Programme, Panum Institute, Copenhagen, Denmark, ${ }^{3}$ Academisch Medisch Centrum bij de Universiteit van Amsterdam, Amsterdam, Netherlands, ${ }^{4}$ Istituto Di Clinica Malattie Infettive e Tropicale, Milan, Italy, ${ }^{5}$ Hospital Clinic i Provincial, Barcelona, Spain, ${ }^{6}$ Royal Sussex County Hospital, Brighton, UK, ${ }^{7}$ Medical University, Gdansk, Poland and ${ }^{8}$ Medical Academy Botkin Hospital, St Petersburg, Russian Federation

* Corresponding author

from Ninth International Congress on Drug Therapy in HIV Infection

Glasgow, UK. 9-13 November 2008

Published: 10 November 2008

Journal of the International AIDS Society 2008, I I (SuppI I):O36 doi:I0.1 I86/I758-2652-I I-SI-O36

This abstract is available from: http://www.jiasociety.org/content/I I/SI/O36

(c) 2008 Bannister et al; licensee BioMed Central Ltd.

\section{Purpose of the study}

The aim of this analysis was to compare the incidence of opportunistic infections (OIs) and death in immunocompromised patients with a CD4 count $\leq 200$ cells $/ \mathrm{mm}^{3}$ across those with:

- viral load (VL) $<500$ copies/mL whilst on combination antiretroviral therapy (cART) ( $\mathrm{VL}<500 \mathrm{c}$ group)

- VL $\geq 500$ copies/mL whilst on cART (VL $\geq 500 \mathrm{c}$ )

- VL $\geq 500$ copies/mL whilst off all ART (VL $\geq 500 \mathrm{nc}$ ).

\section{Methods}

Patients contributed to the person-years at risk if the most recent CD4 count was $\leq 200$ cells $/ \mathrm{mm}^{3}$, and if $\mathrm{VL}$ was measured in the 6 months before the CD4 count. All patients contributing at least one month's follow-up were included. Multivariable analyses were adjusted for current CD4 count, VL, calendar time of follow-up, age, whether or not ART-naive, ethnicity, risk group, hepatitis B and C status, and for death rates, prior AIDS diagnosis.

\section{Summary of results}

4,886 patients were included contributing 7,625 personyears of follow-up (PYFU), during which time 741 OIs and 449 deaths occurred (Table 1). Patients in the VL
$<500$ c group started cART a median time of 1.5 (IQR 0.6-3.7) years prior to baseline, while of 3,524 patients in the $\mathrm{VL} \geq 500$ c group, 1,298 (37\%) had previously been virologically suppressed, a median time of 8 (IQR 4-18) months before baseline. 605 patients $(37 \%)$ in the VL $\geq 500$ nc group had never started cART, and among those that had, the median time since stopping CART was 1.1 (IQR 0.5-C5.4) months.

After adjustment, compared to the $\mathrm{VL}<500$ c group, there was a 2-fold increased incidence of OIs in the $\mathrm{VL} \geq 500 \mathrm{c}$ group and a 4 -fold increased incidence in the $\mathrm{VL} \geq 500 \mathrm{nc}$ group. There was a much higher crude death rate in the $\mathrm{VL}$ $\geq 500$ nc group compared to the other two groups (Table). After adjustment, the death rate in the $\mathrm{VL} \geq 500$ nc group remained over eight times higher than both the $\mathrm{VL}<500 \mathrm{c}$ and $\mathrm{VL} \geq 500$ c groups. When comparing the $\mathrm{VL}<500 \mathrm{c}$ and $\mathrm{VL} \geq 500$ c groups, the lower death rate observed in the $\mathrm{VL}$ $\geq 500$ c group was found to be mostly explained by differences in cART regimen.

\section{Conclusion}

Achieving virological suppression in immunocompromised patients is important for reducing the risk of OIs. Patients on cART have a much lower risk of death than those not receiving CART, regardless of viral suppression. Part of this difference in risk of death may be due to ter- 
Table I:

\begin{tabular}{|c|c|c|c|}
\hline & VL $<500 \mathrm{c}$ & $\mathbf{V L} \geq \mathbf{5 0 0} \mathrm{c}$ & $\mathbf{V L} \geq \mathbf{5 0 0} \mathbf{~ n c}$ \\
\hline PYFU & 3507 & 4274 & 934 \\
\hline Number of Ols & 104 & 414 & 223 \\
\hline Crude event rate $(95 \% \mathrm{Cl})$ & $3.0(2.4-3.5)$ & $9.7(8.8-10.6)$ & $23.9(20.8-27.0)$ \\
\hline Adjusted rate ratio $(95 \% \mathrm{Cl})$ & 1.0 & $1.9(1.5-2.4)$ & $4.3(3.3-5.7)$ \\
\hline \multicolumn{4}{|c|}{5 most commonly occurring Ols, $n$ (\% of all Ols): } \\
\hline Oesophageal candidiasis & II (II\%) & $70(17 \%)$ & $50(22 \%)$ \\
\hline PCP & $6(6 \%)$ & II (3\%) & $21(9 \%)$ \\
\hline Cytomegalovirus (CMV) chorioretinitis & $2(2 \%)$ & $38(9 \%)$ & II (5\%) \\
\hline HIV wasting syndrome & $6(6 \%)$ & 27 (7\%) & II (5\%) \\
\hline Mycobacterial tuberculosis, pulmonary & $6(6 \%)$ & $22(5 \%)$ & $13(6 \%)$ \\
\hline Number of deaths & 86 & 104 & 259 \\
\hline Crude event rate $(95 \% \mathrm{Cl})$ & $2.5(1.9-3.0)$ & $2.4(2.0-2.9)$ & $27.7(24.4-31.1)$ \\
\hline Adjusted rate ratio $(95 \% \mathrm{Cl})$ & 1.0 & $0.7(0.5-1.0)$ & $8.5(6.4-11.1)$ \\
\hline \multicolumn{4}{|l|}{ Median (IQR) } \\
\hline Calendar time of follow-up & 09/0I (06/99-06/04) & $04 / 00(07 / 98-02 / 03)$ & $01 / 01(03 / 99-08 / 03)$ \\
\hline CD4 count (/cells/mm3) & $148(109-178)$ & $118(61-160)$ & $108(50-158)$ \\
\hline VL (log 10 copies/mL) & $1.7(1.7-2.3)$ & $4.4(3.6-5.0)$ & $4.9(4.3-5.4)$ \\
\hline
\end{tabular}

minally ill patients being taken off cART and warrants further analysis of deaths caused by OIs and deaths caused by non-OIs.

Publish with Biomed Central and every scientist can read your work free of charge

"BioMed Central will be the most significant development for disseminating the results of biomedical research in our lifetime. " Sir Paul Nurse, Cancer Research UK

Your research papers will be:

- available free of charge to the entire biomedical community

- peer reviewed and published immediately upon acceptance

- cited in PubMed and archived on PubMed Central

- yours - you keep the copyright

Submit your manuscript here:

http://www.biomedcentral.com/info/publishing_adv.asp 